FUNDAMENTALS

OF

BOTANY

SERIES

PLANT

VARIATION

AND

CLASSIFICATION 
FUNDAMENTALS

OF

BOTANY

SERIES

\author{
edited by \\ WILLIAM A. JENSEN, \\ University of California \\ LEROY G. KAVALJIAN \\ Sacramento State College
}

\title{
THE PLANT CELL
}

William A. Jensen, University of California

REPRODUCTION, HEREDITY, AND SEXUALITY

Stanton A. Cook, University of Oregon

NONVASCULAR PLANTS: FORM AND FUNCTION

William T. Doyle, Northwestern University

VASCULAR PLANTS: FORM AND FUNCTION

Frank B. Salisbury and Robert V. Parke, Colorado State University

PLANTS AND THE ECOSYSTEM

W. D. Billings, Duke University

PLANTS AND CIVILIZATION

Herbert G. Baker, University of California

PLANT VARIATION AND CLASSIFICATION

C. Ritchie Bell, University of North Carolina 
C. Ritchie Bell

UNIVERSITY OF NORTH CAROLINA

\section{PLANT}

\section{VARIATION}

\section{AND}

\section{CLASSIFICATION}

Drawings by Susan Carlton Smith

London

MACMILLAN AND CO., LTD. 
MACMILLAN AND COMPANY LIMITED,

ST. MARTIN'S STREET, LONDON, W.C.2.

$$
\text { also }
$$

BOMBAY, CALCUTTA, MADRAS, MELBOURNE.

ISBN 978-0-333-06258-6 ISBN 978-1-349-00430-0 (eBook)

DOI 10.1007/978-1-349-00430-0 


\section{FOREWORD}

Because of the immensity and complexity of the field of botany, the great diversity of plants, and the many methods of plant study, the problem of how to present to the student the highlights of botanical knowledge gained over the centuries is not easy to solve. The authors and editors of the volumes in this series believe that an understanding of plants - their parts, their activities, and their relationship to manis of fundamental importance in appreciating the significance of life. To stress this concept, the form and function of plants, tissues, and cells are treated together. At all levels of organization, in each volume, information gathered by morphologists, physiologists, cytologists, taxonomists, geneticists, biochemists, and ecologists is combined.

Thus, in the volume on The Plant Cell by William A. Jensen, the structure and function of the various cell parts are discussed together - for example, mitochondria and respiration, photosynthesis and chloroplasts. The volume by Stanton A. Cook, Reproduction, Heredity, and Sexuality, combines the principles of genetics with the means of reproduction in the various plant groups. Nonvascular Plants: Form and Function, by William T. Doyle, and Vascular Plants: Form and Function, by Frank B. Salisbury and Robert V. Parke, cover the major plant groups and discuss the plants in terms of morphology, physiology, and biochemistry. The relation of plants, particularly vascular plants, to their environment and to each other is covered in Plants and the Ecosystem by W. D. Billings. In Plant Variation and Classification, by C. Ritchie Bell, the subject of the identification and classification of vascular plants is examined in relation to patterns of natural variation. Herbert G. Baker, in Plants and Civilization, discusses the importance of plants to man's social and economic development and the equally important consideration of man's role in the modification and distribution of plants.

In a series such as this, the editors are faced with the task of dividing a broad field into areas that can be presented in a meaningful way 
by the authors. There must be logic in the entire scheme, with few gaps and a minimum of overlap. Yet an instructor may not want to use the series of volumes in the sequence and manner preferred by the editors. Consequently, each volume must be usable alone and also in any sequence with the others. To achieve such a high degree of versatility is difficult, but we believe the series exhibits these features.

A concerted effort has been made by the authors and editors to maintain a consistent level of presentation. However, each author has been encouraged to approach his subject in his own way and to write in his own style in order to provide variety and to exploit the uniqueness of the individual author's viewpoint. Finally, while presenting the principles of botany we have tried to communicate the excitement of recent developments as well as the joy that comes with the extension of knowledge in any field.

In this volume the significance of natural patterns of variation is related to the two primary taxonomic processes, classification and identification. A brief introduction is given to some of the general principles and problems of classification; this information is then related to the historic as well as current methods of plant classification. The problem of phenotypic variation versus genetic variation in the delimitation of categories is discussed, as are the relative amounts and kinds of variation that result from different breeding systems. The use of chromosome number and pairing as a taxonomic tool is illustrated, and a later chapter outlines in general terms the current use of various other plant characteristics in both classification and identification. Also, examples are given of some of the biosystematic methods used in the study of variation, evolution, and relationships within a genus or within a species complex. This book differentiates the concepts of plant identification from plant classification by presenting a brief survey of the present rules of botanical nomenclature, a section on the construction and use of keys, and a final chapter on characteristics of some of the major plant families of the north temperate zone. 


\section{CONTENTS}

1. Variation and Classification 1

2. Nomenclature and Keys 12

3. Botanical Classification 27

4. Variation Patterns 40

5. Sources of Variation 50

6. Taxonomic Characteristics 66

7. Correlation, Evaluation, and Presentation of Taxonomic Data 84

8. Plant Families 92

Suggestions for Further Readings, 121

Glossary, 126

Index, 131 